\title{
Light-regulated synthesis of extra- and intracellular enzymes related to wood degradation by the white rot fungus Cerrena unicolor during solid-state fermentation on ash sawdust-based medium
}

\author{
Anna Pawlik ${ }^{\square}$, Magdalena Jaszek, Justyna Sulej and Grzegorz Janusz \\ Department of Biochemistry, Maria Curie-Skłodowska University, Lublin, Poland
}

The light-dependent metabolism of the white rot basidiomycete Cerrena unicolor FCL139 has already been demonstrated using transcriptomic and Biolog-based approaches. To further analyze the influence of light on C. unicolor wood degradation, we measured the activity of an array of CAZymes (carbohydrate-active enzymes) and enzymes involved in the redox system of fungal cells associated with lignolysis. Extra- and intracellular enzymatic extracts were obtained from solid-state ash sawdust $C$. unicolor cultures cultivated for 14 days under red, blue, green, or white light conditions, or in the dark. Light greatly influenced the synthesis of $\mathrm{MnP}$, total cellulases, endo-1,4- $\beta$-glucanase, endo-1,4- $\beta$-xylanase, catalase, and superoxide dismutase. The production of $\mathrm{MnP}$ and catalase was evidently stimulated by white light. It is also worth noticing that blue light caused a gradual increase in the activity of total cellulases throughout the entire period of $C$. unicolor growth. Moreover, endo$1,4-\beta$-glucanase showed the highest activity on day 13 of fungus cultivation and the production of laccase and $\beta$-glucosidase appeared to be the least influenced by light. However, the strongest activity of the endo-1,4- $\beta$ xylanase was observed in the dark. It seemed that light not only influenced the regulation of the synthesis of the wood-degrading enzymes at different levels, but also acted indirectly by affecting production of enzymes managing harmful lignin by-products causing oxidative stress. The ability of the fungus to decompose woody plant material is clearly influenced by environmental factors.

Key words: light conditions, Cerrena unicolor, lignin-modifying enzymes, cellulases, superoxide dismutase, catalase

Received: 28 May, 2019; revised: 06 August, 2019; accepted: 05 September, 2019; available on-line: 07 November, 2019

$\square$ e-mail: anna.pawlik@poczta.umcs.lublin.pl

Acknowledgements od Financial Support: This work was financially supported by the National Science Centre (Poland) based on the decision number DEC-2014/15/B/NZ9/01990.

Abbreviations: CAZYmes, carbohydrate-active enzymes; FPA, filter paper assay; $L M E$, lignin-modifying enzymes; MnP, manganesedependent peroxidase; ROS, reactive oxygen species; SOD, superoxide dismutase

\section{INTRODUCTION}

The lignocellulosic material, the main biomass component, consists of cellulose, hemicellulose, and lignin in various proportions (Jeffries, 1994; Pérez et al., 2002; Sánchez, 2009; Janusz et al., 2017). In nature, it can be degraded by a variety of microorganisms that produce a set of hydrolytic and unique oxidative enzymes working synergistically (Blanchette et al., 1989; Pérez et al., 2002). Complete degradation of cellulose requires the cooperative action of a number of cellulases, xylanolytic and accessory enzymes (Eriksson et al., 1990; Jeffries, 1994; Pérez et al., 2002). Lignin-modifying (LME) and lignindegrading auxiliary (LDA) enzymes are involved in lignin degradation (Janusz et al., 2017). It has also been postulated that some enzymes lacking direct lignin-degrading activities, such as superoxide dismutases (SODs) and catalase, are indispensable in lignolysis. The main role of these enzymes would be to protect their producers from the toxic effects of harmful oxygen species produced during lignin transformation processes (Leonowicz et al., 2001). The main organisms responsible for lignocellulose degradation are the wood-degrading fungi, with the most-known types of brown rot, soft rot, and white rot (Blanchette et al., 1989). Each individual type of the rot fungus produces a specific set of enzymes, degrades different plant material, and thus colonizes diverse ecological niches (Eriksson et al., 1990). Therefore, understanding the physiology and metabolic aptitudes of wood-degrading fungi and the ability to influence their metabolism may have a far-reaching impact not only on future research, but also lead to practical solutions.

Environmental factors greatly affect the decay caused by wood-rotting fungi (Blanchette et al., 1989), and light is undoubtedly one of the most important signals influencing their metabolism (Grassi et al., 2018; Pawlik et al., 2019 b). Sunlight serves as a source of energy or information and can be crucial for successful competition, survival, and development of an organism in nature. In fungi, light controls developmental decisions, physiological adaptations, stress response, and the circadian clock, which is reflected by metabolic changes (Carlile, 1965). Fungi can sense light with a set of discrete photoreceptor proteins, that include flavin-based blue-light, retinal-based green-light (such as rhodopsin), and linear tetrapyrrole-based red-light sensors (Fischer et al., 2016), suggesting that they can detect specific light wavelengths covering the whole white light spectrum and actively respond to these signals.

Cerrena unicolor, a mossy maze polypore, is a globally distributed wood-degrading basidiomycete that causes extensive white rot (Enebak \& Blanchette, 1989; Roody, 2003). C. unicolor strains are also well described as potential bioproducers of industrially relevant enzymes and other bioactive compounds of medical importance (Janusz et al., 2007; Hibi et al., 2012; Belova et al., 2014; Mizerska-Dudka et al., 2015; Sulej et al., 2015). A recent RNAseq-based transcriptomic analysis has provided new 
insights into the differentially expressed C. unicolor genes associated with diverse metabolic and signaling pathways employed by the fungus in response to different lighting conditions (Pawlik et al., 2019a). It has also been demonstrated that the C. unicolor's metabolic aptitudes related to utilization of carbon sources and its chemical sensitivity are also light-dependent (Pawlik et al., 2019b). The dependence of the synthesis of several fungal enzymes on lighting conditions has been analysed as well (Janusz et al., 2016). However, that study was performed using a synthetic mineral (LH) medium, and so far the synthesis of specific enzymes involved in wood decay in the $C$. unicolor fungus grown on natural sawdust medium has not been studied. Moreover, the transcriptomic and Biolog-based analyses are insufficient to fully characterize the light-dependent processes occurring in C. unicolor. There is still a need to confirm the presence of certain wood-related activities and to complement the study with further enzymatic measurements. Given the ability of the fungus to degrade wood material and synthesize biotechnologically significant compounds, a better understanding of light-dependent production of individual enzymes from a natural substrate may be extremely valuable. Furthermore, it can contribute to the development of biotechnological applications of $C$. unicolor and understanding of biochemical changes induced in the fungus by various light conditions.

In this paper we present a comparative analysis of the ability of C. unicolor FCL139 grown in different lighting conditions to synthesize enzymes associated with wood degradation.

\section{MATERIALS AND METHODS}

Fungal strain and cultivation conditions. The strain used in this study was C. unicolor FCL139 from the culture collection of the University of Regensburg, in Regensburg, Germany, deposited in the Fungal Culture Collection (FCL) of the Department of Biochemistry, Maria Curie-Sklodowska University, in Lublin, Poland (Janusz et al., 2012). The stock cultures were maintained on $4 \%(\mathrm{w} / \mathrm{v})$ malt extract agar (Difco, BD, USA) slants. The slants were inoculated with mycelia, incubated at $28^{\circ} \mathrm{C}$ for 10 days, and then used for seed culture inoculation. About $5 \mathrm{~mm}^{2}$ of the slants were punched out with a sterilized cutter and used as inoculum. Then, the mycelia of each strain were transferred into a 100-ml liquid Lindeberg-Holm (LH) medium (1952). The seeds were cultivated in the dark at $28^{\circ} \mathrm{C}$. Next, the ten-dayold mycelia were homogenized in a disperser homogenizer (IKA, Staufen, Germany) and used as a standard inoculum. Solid-state lignocellulose $C$. unicolor cultures were grown at $28^{\circ} \mathrm{C}$ on $1 \mathrm{~g}$ of sterile ash sawdust (wood particles $<4 \mathrm{~mm}$ ) soaked with $9 \mathrm{ml}$ of distilled water in Erlenmeyer flasks placed in incubators (KT 115, Binder, Germany) equipped with illumination LED cassettes for 14 days. The following lighting variants were applied: white (4000-4750 K), green (510-520 nm), blue (465$470 \mathrm{~nm})$, red (620-625 nm) light, and darkness. Continuous lighting conditions (20 lux) were provided throughout the entire period of $C$. unicolor cultivation.

Preparation of sawdust enzymatic extracts. Extracellular enzymes extracts were obtained from solid-state lignocellulose $C$. unicolor cultures. For this purpose, $10 \mathrm{ml}$ of deionized water was added to each Erlenmayer flask, and the sawdust medium overgrown with the mycelium was gently crushed with a glass rod. Next, the suspension was stirred for 5 minutes using a magnetic stirrer and the enzymatic extract was separated from the residues by filtration using Whatman No. 1 qualitative filter paper.

Intracellular extracts were prepared using $4 \mathrm{~g}$ of ash sawdust overgrown with the mycelium. The samples were homogenized on ice (4 min processing cycle of $30 \mathrm{~s}$ pulses per min, $80 \%$ amplitude) in $15 \mathrm{ml}$ of icechilled distilled water in an ultrasonic homogenizer (Vibra-Cell, Sonics and Materials, Inc., USA). Immediately after sonication, each sample was filtered through Miracloth and the homogenates were centrifuged $(10000 \times g$, $\left.15 \mathrm{~min}, 4^{\circ} \mathrm{C}\right)$. Clear supernatant fractions were then aliquoted, frozen, and kept at $-20^{\circ} \mathrm{C}$.

Clear extra- and intracellular enzymatic filtrates were used as a source of the crude enzymatic preparation subjected to further measurements as described below.

Wood-related enzymatic activity assays. All the spectrophotometric measurements were performed using an Infinite 200 Pro microplate reader (Tecan, Germany) in triplicates in three biological replications.

Aryl-alcohol dehydrogenase [EC 1.1.1.91, AAD] activity was determined by measuring NADPH-dependent reduction of veratraldehyde (3,4-dimethoxybenzaldehyde) at pH 6.0 (Muheim et al., 1991; Guillén \& Evans, 1994). One unit of AAD activity was defined as the amount of enzyme that oxidizes one $\mu$ mole of NADPH to NADP per minute at $30^{\circ} \mathrm{C}$.

Cellobiose dehydrogenase [EC 1.1.3.25, CDH] activity was measured by following the decrease in absorbance of the electron acceptor 2,6-dichloroindophenol at $520 \mathrm{~nm}$ $\left(\varepsilon^{\mathrm{M}}=6.8 \mathrm{mM}^{-1} \mathrm{~cm}^{-1}\right), \mathrm{pH} 4.5$ and $30^{\circ} \mathrm{C}$ (Baminger et al., 2001; Karapetyan et al., 2006). This assay measures the activity of an intact enzyme and that of the catalytically active flavin domain. The final enzyme activity was expressed as nanokatals per liter (nkat/l).

Laccase [EC 1.10.3.2] activity was measured spectrophotometrically at $525 \mathrm{~nm}$ with syringaldazine as a substrate (Leonowicz \& Grzywnowicz, 1981). One unit of laccase activity was defined as the amount of the enzyme needed to catalyze the production of one nanomole of colored product (quinone, $\varepsilon^{\mathrm{M}}=65000 \mathrm{M}^{-1} \mathrm{~cm}^{-1}$ ) per second at $25^{\circ} \mathrm{C}$ and $\mathrm{pH}$ 5.5. The activity was expressed as nanokatals per liter of the enzymatic filtrate (nkat/l).

Catalase [EC 1.11.1.6] activity was determined indirectly using catalase assay kit, according to the producer's protocol (Sigma-Aldrich, USA) (Fischer et al., 2016). It is based on the measurement of the hydrogen peroxide substrate remaining after the enzyme's action on 3,5-dichloro-2-hydroxybenzenesulfonic acid. In the presence of horseradish peroxidase (HRP), a red quinoneimine dye is formed which absorbs $520 \mathrm{~nm}$ light. One unit of catalase was defined as the amount of the enzyme needed to catalyze the decomposition of $1 \mu$ mole of hydrogen peroxide to oxygen and water per minute at $\mathrm{pH} 7.0$ at $25^{\circ} \mathrm{C}$, at a substrate concentration of $50 \mathrm{mM}$ hydrogen peroxide.

Manganese-dependent peroxidase [EC 1.11.1.13, MnP] activity was determined with a method described by Wariishiand others (Wariishi et al., 1992) modified by Hofrichter and others (Hofrichter et al., 1999). The reaction was initiated by adding $\mathrm{H}_{2} \mathrm{O}_{2}$, and the rate of $\mathrm{Mn}^{3+}$ malonate complex formation was monitored by measuring the increase in absorbance at $270 \mathrm{~nm}\left(\varepsilon^{\mathrm{M}=11590 \mathrm{M}^{-1}}\right.$ $\mathrm{cm}^{-1}$ ). The enzyme activity was expressed as nanokatals per litre (nkat/l).

Lignin peroxidase [EC 1.11.1.14, LiP] activity was determined using the oxidation of veratryl alcohol method as described by Arora and Gill (Arora \& Gill, 2001). The reaction was initiated by $\mathrm{H} 2 \mathrm{O} 2$, and the change in ab- 
sorbance was monitored at $310 \mathrm{~nm}\left(\varepsilon^{\mathrm{M}}=9300 \mathrm{M}^{-1} \mathrm{~cm}^{-1}\right)$. The enzyme activity was expressed as nanokatals per litre (nkat/l).

Superoxide dismutase [EC 1.15.1.1, SOD] activity was measured spectrophotometrically at $450 \mathrm{~nm}$ using WST-1 (2-(4-iodophenyl)-3-(4-nitrophenyl)-5-(2,4-disulfophenyl)-2H-tetrazolium sodium salt as a substrate with an indirect assay method based on xanthine oxidase as described in the SOD activity determination kit (Sigma-Aldrich, USA). The SOD activity was expressed as percentage of inhibition.

Endo-1,4- $\beta$-glucanase [EC 3.2.1.4, endo-cellulase] activity was determined using 4,6-O-(3-ketobutylidene)-4-nitrophenyl- $\beta$-D-cellopentaoside substrate in an automated assay procedure as described in the CellG5 method (Megazyme, Ireland) (Mangan et al., 2016). One unit of endo- $\beta$-1,4-glucanase activity (CellG5 Unit/ml) equals the amount of enzyme required to release $1 \mu$ mole of $p$-nitrophenol per minute in the assay conditions.

Endo-1,4- $\beta$-xylanase [EC 3.2.1.8, endo-xylanase] activity was determined using 4,6-O-(3-ketobutylidene)-4-nitrophenyl- $\beta-\mathrm{D}-45$-glucosyl-xylopentaoside colorimetric reagent with an automated assay procedure according to the XylX6 method (Megazyme, Ireland) (Mangan et al., 2017). One unit of endo-1,4- $\beta$-xylanase activity (XylX6 Unit/ml) is equal to the amount of enzyme required to release 1 $\mu$ mole of $p$-nitrophenol per minute under test conditions.

$\beta$-1,4-glucosidase [EC 3.2.1.21] activity was measured at $400 \mathrm{~nm}$ with $p$-nitrophenyl- $\beta$-D-glucopyranoside as a substrate (Ghose \& Bisaria, 1987). One unit of $\beta$-glucosidase activity $(\mathrm{U} / \mathrm{ml})$ was expressed as the amount of enzyme required to release $1 \mu$ mole of $p$-nitrophenol per minute in the assay conditions.

$\beta$-glucuronidase [EC 3.2.1.31] activity was measured at $400 \mathrm{~nm}$ with $p$-nitrophenyl- $\beta$-D-glucuronide as a substrate (Kuroyama et al., 2001). One unit of $\beta$-glucuronidase activity $(\mathrm{U} / \mathrm{ml})$ was expressed as the amount of enzyme required to release $1 \mu$ mole of $p$-nitrophenol per minute under assay conditions.

$\beta$-xylosidase [EC 3.2.1.37] activity was measured at $400 \mathrm{~nm}$ with $p$-nitrophenyl- $\beta$-D-xylopyranoside as a sub- strate (John \& Schmidt, 1988). One unit (U/ml) of $x y-$ losidase activity was expressed as the amount of enzyme required to release $1 \mu$ mole of $p$-nitrophenol per minute under assay conditions.

$\beta$-mannanase [EC 3.2.1.78] activity was determined using $0.5 \%(\mathrm{w} / \mathrm{v})$ locust bean gum as a substrate $(\mathrm{Na}-$ ganagouda et al., 2009). The amount of reducing sugars produced in the enzyme reaction was measured as D-mannose reducing equivalents with the 3,5-dinitrosalicylic acid method (Miller, 1959) at $540 \mathrm{~nm}$. One unit of mannanase activity $(\mathrm{U} / \mathrm{ml})$ was expressed as the amount of enzyme that liberates $1 \mu$ mole of mannose during 1 minute at $50^{\circ} \mathrm{C}$.

Total cellulase activity was measured with the filter paper method (FPA) using $50 \mathrm{mg}$ of Whatman No. 1 filter paper as described by (Ghose, 1987). The reducing sugars released were measured using the 3,5-dinitrosalicylic acid method (Miller, 1959). One unit of cellulases activity $(\mathrm{U} / \mathrm{ml})$ was expressed as the amount of enzyme that liberates $1 \mu$ mole of glucose during 1 minute at $50^{\circ} \mathrm{C}$.

Statistical analysis. All measurements were performed in triplicates in three independent biological replications. All results are expressed as the mean \pm S.D. (standard deviation) for nine measurements $(n=9)$.

\section{RESULTS}

To detect and measure the activity of white rot basidiomycete C. unicolor FCL139 enzymes engaged in wood degradation in different lighting conditions, an array of CAZymes (carbohydrate-active enzymes, including cellulolytic, hemicellulolytic, lignin-degrading enzymes) and enzymes involved in the redox system of fungal cells associated with ligninolysis was tested in the sawdust medium cultures under red, blue, green, white light and darkness conditions. Extra- and intracellular enzymatic extracts were obtained from solid-state ash sawdust C. unicolor cultures cultivated for 14 days in controlled lighting conditions.

In general, the synthesis of specific wood-degrading enzymes, i.e.: laccase, $\mathrm{MnP}, \beta$-glucosidase, endo-1,4- $\beta$ -
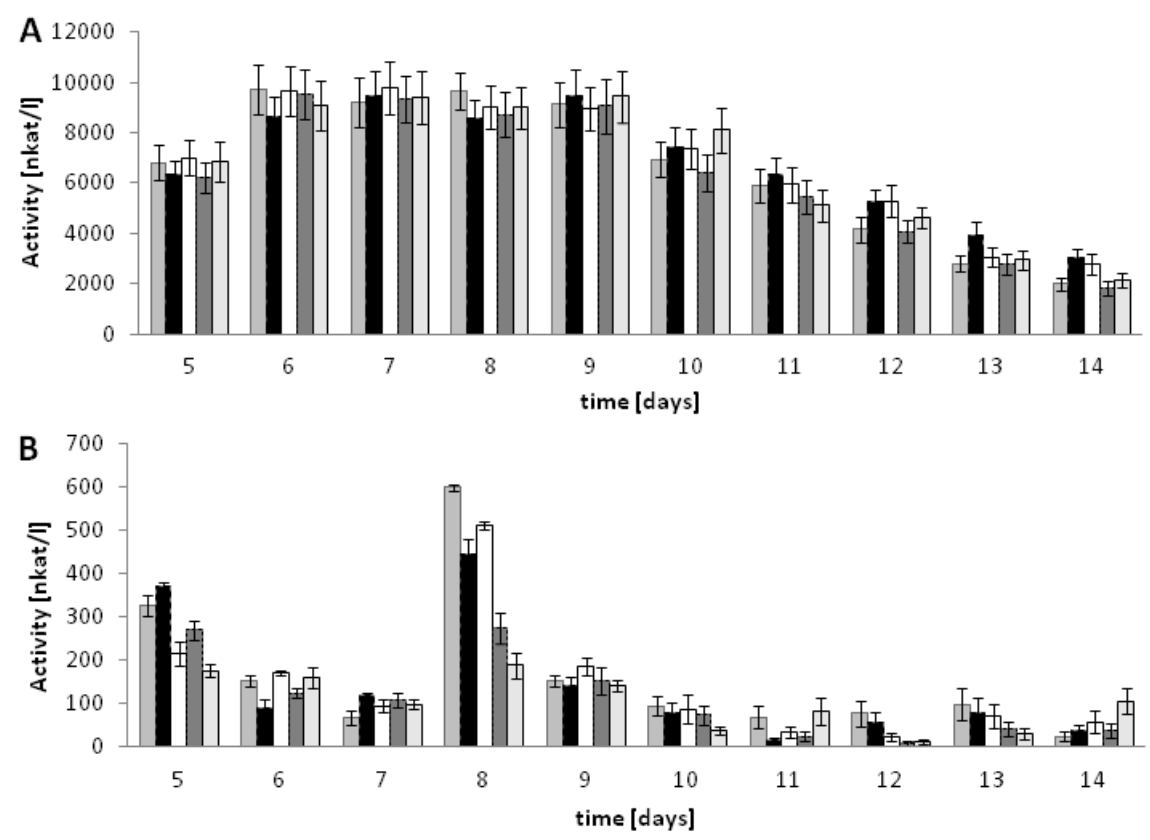

Figure 1. Extracellular activities of lignolytic enzymes (A) laccase and (B) MnP produced by C. unicolor during 14 days of cultivation on ash sawdust medium in the dark $(\square)$ or under white $(\square)$, red $(\square)$, blue $(\square)$, or green ( $)$ lighting conditions. 

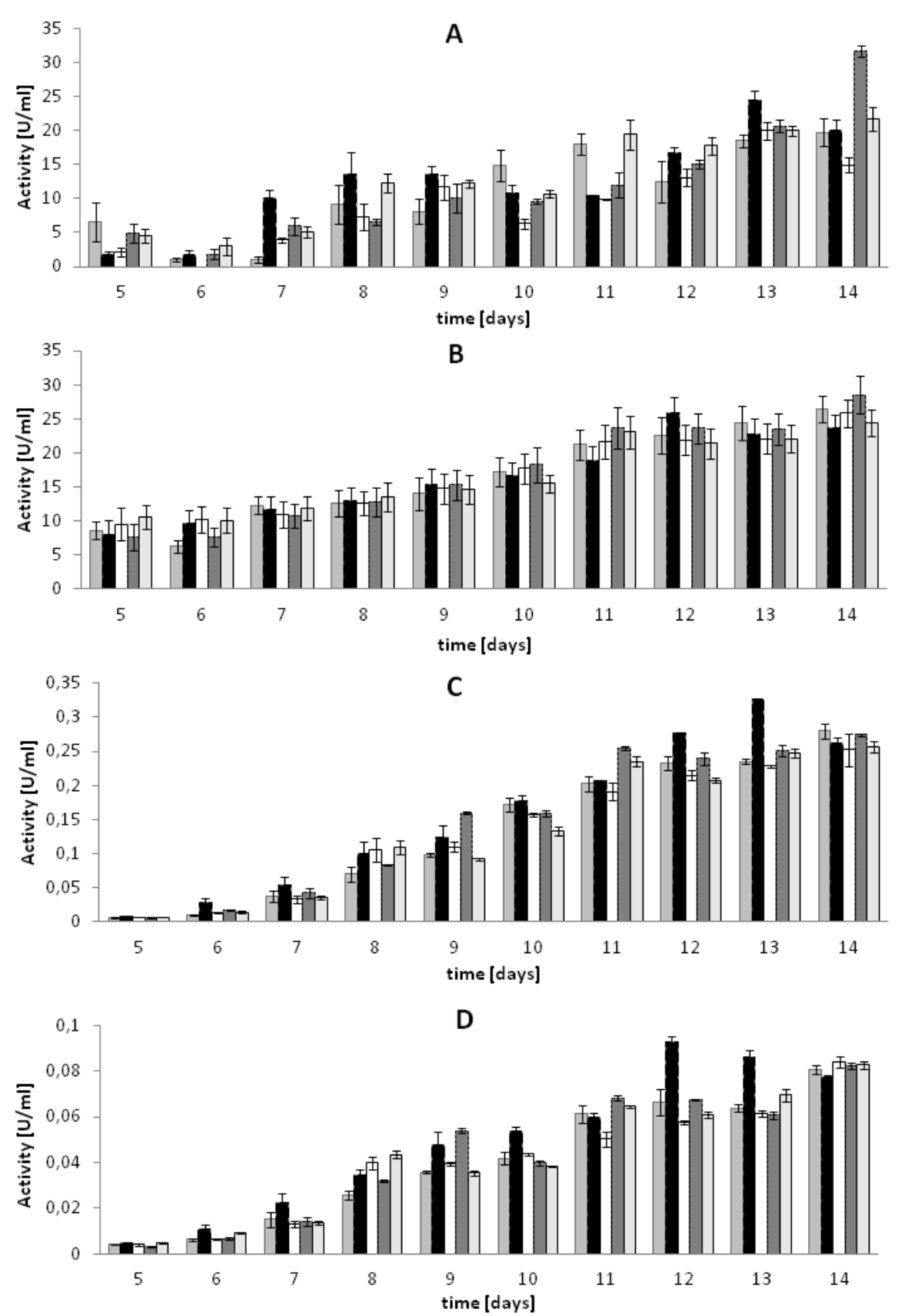

Figure 2. Cellulo- and xylanolytic activities of $(A)$ total cellulases, (B) $\beta$-glucosidase, (C) endo- $\beta$-1,4-glucanase, and (D) endo- $\beta$-1,4xylanase produced by $C$. unicolor during 14 days of cultivation on ash sawdust medium in the dark ( $\square$ ) or under white ( $\square$ ), red ( $\square$ ), blue ( $\square)$, or green ( ) lighting conditions.

glucanase, endo-1,4- $\beta$-xylanase, and total cellulases took place in all lighting variants. When the ash sawdust medium was used as a source of nutrients, the production of laccase, MnP, $\beta$-glucosidase, endo-1,4- $\beta$-glucanase, endo$1,4-\beta$-xylanase, SOD, catalase, and total cellulolytic activity in $C$. unicolor was observed regardless of the lighting conditions. In turn, low enzymatic activities or no activity was observed for AAD, CDH, LiP, $\beta$-glucuronidase, $\beta$-xylosidase, and $\beta$-mannanase (data not shown). C. unicolor was not able to synthesize these enzymes effectively when the sawdust medium was used.

The highest activities for lignin-modifying enzymes (LME) were observed from the 6th to 9th day of cultivation for laccase and on 8th day of cultivation for MnP (Fig. 1). The cellulolytic and xylanolytic activities gradually increased over time and reached their maximum on cultivation days 11 to 14 (Fig. 2). The synthesis of SOD was highly variable. Nonetheless, the SOD inhibition rate ranged from 61 to $81 \%$ during the entire period of C. unicolor cultivation. The highest inhibition rate was present under red light cultivation conditions (73-81\%) and the lowest value was found for blue light cultivation conditions $(61-76 \%)$ (Fig. 3A). In turn, catalase activities remained at a high level from culture day 5 to 9 (Fig. 3B).

In general, light influenced the synthesis of $\mathrm{MnP}$, total cellulases, endo-1,4- $\beta$-glucanase, endo-1,4- $\beta$-xylanase, catalase, and SOD. The synthesis of MnP was stimulated by white light, and its maximal enzymatic activity (598 nkat/l) was observed on day 8 of the culture. High $\mathrm{MnP}$ activities were also noticed under the red light (510 nkat/l) and dark (444 nkat/l) conditions (Fig. 1B). Strong 

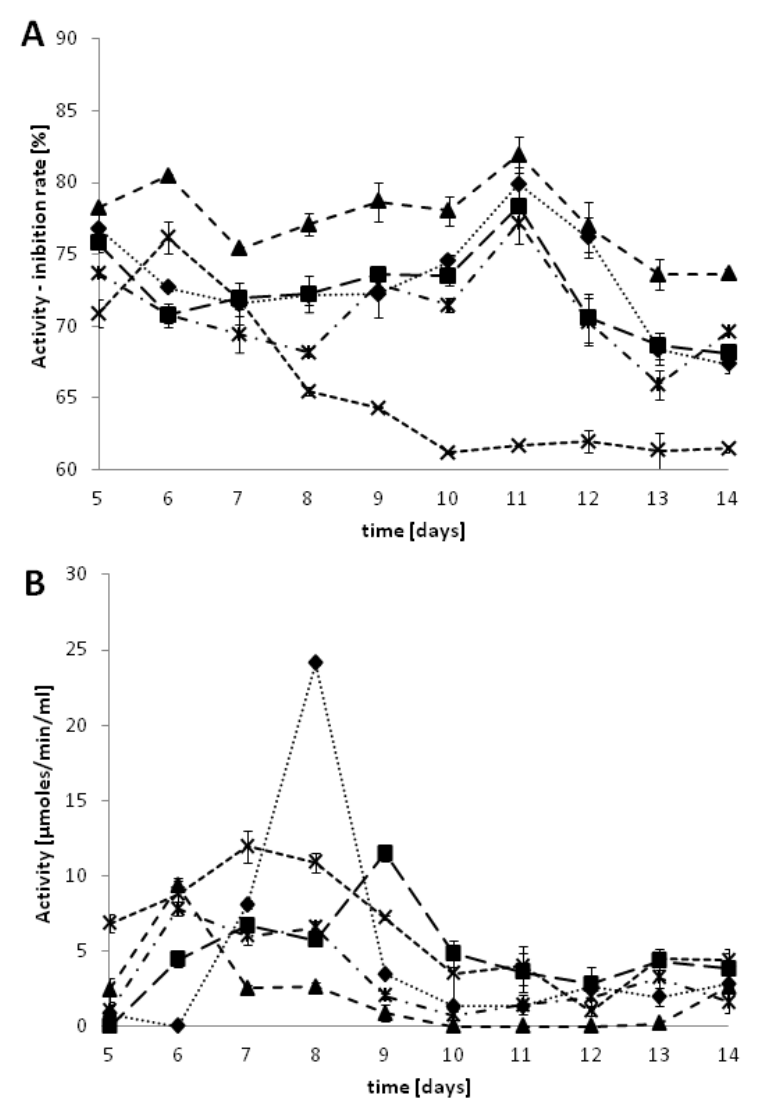

Figure 3. Intracellular activities of the enzymes involved in the fungal redox system. (A) SOD and (B) catalase produced by $C$. unicolor during 14 days of cultivation on ash sawdust medium in the dark $(\square)$ or under white $(\boldsymbol{\nabla})$, red $(\boldsymbol{\Delta})$, blue $(X)$, or green $(\star)$ lighting conditions.

stimulation of enzymatic activity by white light was also proved for catalase, and its maximal activity $(24 \mathrm{U} / \mathrm{ml})$ was noted on day 8 of C. unicolor cultivation. Moreover, the blue light and dark conditions also significantly increased catalase activity on the 7-8th and the 9th day of culture, respectively (Fig. 3B).

A large variety of enzymatic profiles was obtained for the total saccharifying cellulases activity assessed with the FPA method (Fig. 2A). Darkness and green light maximally stimulated cellulolytic activity on culture day 8, when compared to red and blue lighting conditions, on day 9 when compared to white lighting conditions, and on day 12 when compared to white, red, and blue lighting conditions. Moreover, on the 13th day of fungus cultivation in the dark, the cellulases activity was increased compared to all lighting conditions. Meanwhile, on the 10th and 11th day of cultivation the increase in cellulases synthesis was due to the white vs. dark, red, blue, and green light and white and green vs. dark, red, and blue light conditions, respectively. It is worth noticing that blue light caused a gradual increase in total cellulases activity throughout the entire period of $C$. unicolor cultivation, in the range from $5 \mathrm{U} / \mathrm{ml}$ on day 5 to $31 \mathrm{U} /$ $\mathrm{ml}$ on day 14.

The specific enzymes engaged in cellulose degradation showed varied levels of activity in the later period of fungus cultivation, starting from day 11. Endo-1,4$\beta$-glucanase (endo-cellulase) showed the highest activity on day 13 . In turn, these activities were $25-30 \%$ lower when other than dark lighting conditions were applied (Fig. 2C). Slight light-dependent differences in $\beta$-glucosidase synthesis were also proved for various culture days (Fig. 2B). Of all the cellulose degrading enzymes tested, light under these cultivation conditions had the least effect on the production of laccase and $\beta$-glucosidase (Fig. 1A and 2B). Laccase reached its maximal activity of about 9000-10000 nkat/1 between day 6 and 9 in all the culture lighting variants.

The greatest effect of light on enzymatic activity was observed for the xylanolytic enzyme, i.e. endo-1,4- $\beta$ xylanase (endo-xylanase). The strongest stimulation of its activity was noted in $C$. unicolor cultivated in the dark. Endo-xylanase was produced most efficiently on days 12 and 13 , with maximal activity reaching about $0.09 \mathrm{U} / \mathrm{ml}$. In comparison, the activities reached under other lighting conditions were in the range of $0.05-0.06 \mathrm{U} / \mathrm{ml}$, that is over 30\% lower (Fig. 2D).

\section{DISCUSSION}

The kingdom of fungi comprises of species living in various ecological niches, but the life of them all depends on the bioavailability of organic matter, oxygen, water, and light. Light has focused special attention in recent years, as it affects metabolism and behaviour of fungi in a different way than in known living organisms. In contrast to plants, fungi use light as a source of information and not as a source of energy (Carlile, 1965). As suggested before, fungi can sense a full spectrum of light through a variety of photoreceptors. Our previous research proved that $C$. unicolor, like many other fungal organisms, is potentially sensitive to a variety of light wavelengths (Pawlik et al., 2019a). Also, the influence of light on C. unicolor laccase, cellobiose dehydrogenase, and proteases synthesis in two different media (mineral and cellulose-containing) has been analysed (Janusz et al., 2016). The results obtained in this study clearly indicate that fungal enzyme activity is not only affected by lighting conditions but also relies on medium composition. Therefore, it seems that light may exert a different effect on fungal metabolism depending on the availability of nutritional substances in the environment. Hence, in the optimal nutritional conditions, the growth-related metabolism should be approximately equal in the light and in the dark, but alterations in these conditions would affect the metabolic processes differently depending on the lighting status (Carlile, 1965). It has been proved that light regulates gene expression in Trichoderma reesei and the genes encoding CAZYmes are clustered together in the genome (Schmoll, 2018a). Therefore, it is hard to compare different fungal organisms growing in different media in the same lighting conditions. Moreover, since fungi have several photoreceptors, diverse reactions may be observed to different light wavelengths. Blue and red light greatly influence gene expression and transcriptional machinery, but it is still unclear how green light transmembrane photoreceptors affect fungal metabolism $\mathrm{Yu}$ \& Fischer, 2019). Furthermore, the multiyear research on Neurospora crassa suggests that also epigenetics and posttranslational modification must be considered (Proietto et al., 2015). Therefore, it is hard to understand which photoreceptor is responsible for enzyme synthesis when only white and dark variants are used.

The gradual increase in the $C$. unicolor cellulolytic and xylanolytic activities over cultivation time may be related to the use of a natural sawdust medium and its bioavailability of cellulosic and hemicellulosic polymers for fungal degradation. The FPA method used for total saccharifying cellulases activity measurement gave back 
a large diversity of enzymatic profiles, which is not surprising since the method measures the overall cellulose hydrolyzing capacity of enzymatic extracts. These results proved that production of cellulases by $C$. unicolor may be regulated, inter alia, by green light, and it seems that a detailed mechanism of such regulation cannot be revealed at this stage of research and further analyses are required. Since the green-light photoreceptor may be a proton pump (Bieszke et al., 1999), it is possible that the fungus is changing $\mathrm{pH}$ in its close environment, thus activating extracellular enzymes. In our previous research, a slight increase in $\beta$-glucosidase transcripts was observed when $C$. unicolor was grown in the same medium in green lighting conditions (Pawlik et al., 2019a). The results obtained previously suggested that, of all the wavelengths tested, green light affected the lowest number of wooddegrading enzymes. However, among them was one cellulase, and it is probable that this light wavelength may also regulate enzyme synthesis at the gene expression level. Moreover, the highest activities of cellobiose dehydrogenase were observed for the fungus maintained in cellulose-based medium (Janusz et al., 2016). It should be noted that even if $\mathrm{CDH}$ is engaged in cellulose degradation, no activities of this enzyme were detected in the ash sawdust medium, irrespective of the lighting conditions.

Our results showed that both white and red light boosted up $\mathrm{MnP}$ activities, which agrees with the transcriptomic analysis and supports the idea that red light regulates enzyme synthesis transcriptionally. Similarly, the transcriptomic and biochemical assays showed related results for laccase, whose activity did not seem to be influenced by light when the fungus was grown in ash sawdust, in contrast to the Lindeberg and Holm medium, when differential regulation of laccase synthesis was observed as different lighting conditions were applied (Janusz et al., 2016). It is possible that laccase production by $C$. unicolor is strictly regulated by carbon repression, which is easily observed in glucose-containing medium (Janusz et al., 2013). It has been shown in T. reesei that cellulases synthesis in darkness is regulated by YPR2 transcription factors, which also involved synthesis of carbon catabolite repressor CRE1 (Hitzenhammer et al., 2019). The same repressor has been proved to influence the synthesis of lignolytic enzymes (Janusz et al., 2013), cellulases (Bischof et al., 2016), and hemicellulases (Amore et al., 2013). Moreover, it may also affect fungal growth, virulence, morphology, and utilisation of nonglucose sources (Adnan et al., 2018).

It should be emphasized that light may be considered as a stress factor for microbial organisms and can provide information that the cell has been exposed to hazardous conditions (UV or drying). Fungal blue-light photoreceptors have been proposed as integrators of light and oxidative stress (Osorio-Concepcion et al., 2017). Therefore, the blue light may rather cause a cascade of several processes associated with reaction to stress than the synthesis of enzymes related to carbohydrate metabolism (Schmoll, 2018b). In fungi, exposure to light appears to prepare cells for oxidative stress by upregulating the expression of catalase and superoxide dismutase (Andries et al., 2016; Igbalajobi et al., 2019). Moreover, it is possible that both light and oxidative stress regulate the asexual-sexual switch via light-responsive and ROS (reactive oxygen species) pathways, as already proved in the model fungus $N$. crassa (Wang et al., 2018). In the same fungus, cellular ROS levels were managed by one catalase isoform, whose expression varied as a function of circadian clock (Yoshida et al., 2011). Other possible processes related to light and SOD are conidiation and synthesis of carotenoids (Yoshida et al., 2008). In the case of wood-degrading fungi, oxidative stress may be a result of the accumulation of lignin degradation products, and light-driven up-regulation of the enzymes described above may be helpful to cope with high ROS levels (Leonowicz et al., 2001).

In summary, light affects wood degradation by fungal organisms to the same extent as the entire microbial metabolism. It seems that this applies not only to the multi-level regulation of the synthesis of wood-degrading enzymes, but also indirectly to the production of enzymes that manage the harmful by-products of lignin degradation that cause oxidative stress. However, compared to model organisms $N$. crassa or T. reesei, little is known about the effect of light on $C$. unicolor metabolism. Future studies using different techniques can help to address this issue.

\section{REFERENCES}

Adnan M, Zheng WH, Islam W, Arif M, Abubakar YS, Wang ZH, Lu GD (2018) Carbon catabolite repression in filamentous fungi. Int. J. Mol. Sci. 19: 48. https://doi.org/10.3390/Ijms19010048

Amore A, Giacobbe S, Faraco V (2013) Regulation of cellulase and hemicellulase gene expression in fungi. Curr. Genomics. 14: 230-249. https://doi.org/10.2174/1389202911314040002

Andries M, Pricop D, Oprica L, Creanga DE, Iacomi F (2016) The effect of visible light on gold nanoparticles and some bioeffects on environmental fungi. Int. J. Pharmaceut. 505: 255-261. https://doi. org/10.1016/j.ijpharm.2016.04.004

Arora DS, Gill PK (2001) Comparison of two assay procedures for lignin peroxidase. Enzyme Microb. Technol. 28: 602-605. https://doi. org/10.1016/S0141-0229(01)00302-7

Baminger U, Subramaniam SS, Renganathan V, Haltrich D (2001) Purification and characterization of cellobiose dehydrogenase from the plant pathogen Sclerotium athelia rolfsii. Appl. Environ. Microbiol. 67: 1766-1774. https://doi.org/10.1128/aem.67.4.1766-1774.2001

Belova OV, Lisov AV, Vinokurova NG, Kostenevich AA, Sapunova LI, Lobanok AG, Leontievsky AA (2014) Xylanase and cellulase of fungus Cerrena unicolor VKM F-3196: Production, properties, and applications for the saccharification of plant material. Appl. Biochem. Microbiol. 50: 148-153. https://doi.org/10.1134/s0003683814020057

Bieszke JA, Braun EL, Bean LE, Kang S, Natvig DO, Borkovich KA (1999) The nop-1 gene of Neurospora crassa encodes a seven transmembrane helix retinal-binding protein homologous to archaeal rhodopsins. Proc Natl Acad Sci USA 96: 8034-8039. https://doi. org/10.1073/pnas.96.14.8034

Bischof RH, Ramoni J, Seiboth B (2016) Cellulases and beyond: the first 70 years of the enzyme producer Trichoderma reesei. Microb. Cell Fact. 15: 106. https://doi.org/10.1186/S12934-016-0507-6

Blanchette RA, Nilsson T, Daniel G, Abad A (1989). Biological degradation of wood: properties, chemistry and preservation. In $A r$ chaeological wood. Rowell R, Barbour R eds, pp 141-174. American Chemical Society.

Carlile MJ (1965) Photobiology of fungi. Ann. Rev. Plant Physio. 16: 175-202. https://doi.org/10.1146/annurev.pp.16.060165.001135

Enebak SA, Blanchette RA (1989) Canker formation and decay in sugar maple and paper birch infected by Cerrena unicolor. Can. J. Forest Res. 19: 225-231. https://doi.org/10.1139/X89-031

Eriksson K-EL, Blanchette RA, Ander P (1990) Morphological aspects of wood degradation by fungi and bacteria. In Microbial and enzymatic degradation of wood and wood components, pp 1-87. Springer Berlin Heidelberg.

Fischer R, Aguirre J, Herrera-Estrella A, Corrochano LM (2016) The complexity of fungal vision. Microbiol. Spectr. 4. https://doi. org/10.1128/microbiolspec.FUNK-0020-2016

Fossati P, Prencipe L, Berti G (1980) Use of 3,5-dichloro-2-hydroxybenzenesulfonic acid/4-aminophenazone chromogenic system in direct enzymic assay of uric acid in serum and urine. Clin. Chem. 26: 227-231. PMID: 7353268

Ghose TK (1987) Measurement of cellulase activities. Pure Appl. Chem. 59: 257-268. https://doi.org/ 10.1351/pac198759020257

Ghose TK, Bisaria VS (1987) Measurement of hemicellulase activities. 1. Xylanases. Pure Appl.Chem. 59: 1739-1751. https://doi. org/10.1351/pac198759121739

Grassi E, Robledo G, Levin L (2018) Influence of light on lignin-degrading activities of fungal genus Polyporus s. str. J. Basic Microbiol. 58: 947-956. https://doi.org/10.1002/jobm.201800183 
Guillén F, Evans CS (1994) Anisaldehyde and veratraldehyde acting as redox cycling agents for $\mathrm{H}_{2} \mathrm{O}_{2}$ production by Pleurotus eryngii. Appl. Environ. Microbiol. 60: 2811-2817

Hibi M, Hatahira S, Nakatani M, Yokozeki K, Shimizu S, Ogawa J (2012) Extracellular oxidases of Cerrena sp. complementarily functioning in artificial dye decolorization including laccase, manganese peroxidase, and novel versatile peroxidases. Biocatal. Agric. Biotechnol. 1: $220-225$

Hitzenhammer E, Buschl C, Sulyok M, Schuhmacher R, Kluger B, Wischnitzki E, Schmoll M (2019) YPR2 is a regulator of light modulated carbon and secondary metabolism in Trichoderma reesei. BMC Genomics. 20. https://doi.org/10.1186/S12864-019-5574-8

Hofrichter M, Vares T, Kalsi M, Galkin S, Scheibner K, Fritsche W, Hatakka A (1999) Production of manganese peroxidase and organic acids and mineralization of 14C-labelled lignin (14C-DHP) during solid-state fermentation of wheat straw with the white rot fungus Nematoloma frowardii. Appl. Environ. Microbiol. 65: 1864-1870

Igbalajobi O, Yu Z , Fischer R (2019) Red- and blue-light sensing in the plant pathogen Alternaria alternata depends on phytochrome and the white-collar protein LreA. mBio. 10. https://doi.org/10.1128/ mBio.00371-19

Janusz G, Rogalski J, Szczodrak J (2007) Increased production of laccase by Cerrena unicolor in submerged liquid cultures. World J. Microbiol. Biotechnol. 23: 1459-1464. https://doi.org/10.1007/s11274-0079390-y

Janusz G, Mazur A, Chęcińska A, Małek W, Rogalski J, Ohga S (2012) Cloning and characterization of a lacease gene from biotechnologically important basidiomycete Cerrena unicolor. J. Fac. Agric. Kyushu Univ. 57: 41-49

Janusz G, Kucharzyk KH, Pawlik A, Staszczak M, Paszczynski AJ (2013) Fungal laccase, manganese peroxidase and lignin peroxidase: gene expression and regulation. Enzyme Microb. Technol. 52: 1-12. https://doi.org/10.1016/j.enzmictec.2012.10.003

Janusz G, Sulej J, Jaszek M, Osińska-Jaroszuk M (2016) Effect of different wavelengths of light on laccase, cellobiose dehydrogenase, and proteases produced by Cerrena unicolor, Pycnoporus sanguineus, and Phlebia lindtneri. Acta Biochim. Pol. 63: 223-228. https://doi. org/10.18388/abp.2015_1235

Janusz G, Pawlik A, Sulej J, Swiderska-Burek U, Jarosz-Wilkolazka A, Paszczynski A (2017) Lignin degradation: microorganisms, enzymes involved, genomes analysis and evolution. FEMS Microbiol. Rev. 41: 941-962. https://doi.org/10.1093/femsre/fux049

Jeffries TW (1994) Biodegradation of lignin and hemicelluloses. In Biochemistry of microbial degradation. Ratledge C, ed, pp 233-277. Springer Netherlands

John M, Schmidt J (1988) Xylanases and $\beta$-xylosidase of Trichoderma lignorum. In Methods in ensymology, pp 662-671. Academic Press

Karapetyan KN, Fedorova TV, Vasil'chenko LG, Ludwig R, Haltrich D, Rabinovich ML (2006) Properties of neutral cellobiose dehydrogenase from the ascomycete Chaetomium sp. INBI 2-26(-) and comparison with basidiomycetous cellobiose dehydrogenases. J. Biotechnol. 121: 34-48. https://doi.org/10.1016/j.jbiotec.2005.06.024

Kuroyama H, Tsutsui N, Hashimoto Y, Tsumuraya Y (2001) Purification and characterization of a $\beta$-glucuronidase from Aspergillus niger. Carbohydr. Res. 333: 27-39. https://doi.org/10.1016/S00086215(01)00114-8

Leonowicz A, Grzywnowicz K (1981) Quantitative estimation of laccase forms in some white-rot fungi using syringaldazine as a substrate. Enzyme Microb. Technol. 3: 55-58. https://doi. org/10.1016/0141-0229(81)90036-3

Leonowicz A, Cho N, Luterek J, Wilkolazka A, Wojtas-Wasilewska M, Matuszewska A, Hofrichter M, Wesenberg D, Rogalski J (2001) Fungal laccase: properties and activity on lignin. J. Basic Microbiol. 41: 185-227. https://doi.org/10.1002/15214028(200107)41:3/4<185::aid-jobm185>3.0.co;2-t

Lindeberg G, Holm G (1952) Occurrence of tyrosinase and laccase in fruit bodies and mycelia of some hymenomycetes. Physiol. Plantarum. 5: 100-114. https://doi.org/10.1111/j.1399-3054.1952.tb08234.x

Mangan D, Cornaggia C, McKie V, Kargelis T, McCleary BV (2016) A novel automatable enzyme-coupled colorimetric assay for endo-1,4- $\beta$-glucanase (cellulase). Anal. Bioanal. Chem. 408: 4159-4168. https://doi.org/10.1007/s00216-016-9507-y

Mangan D, Cornaggia C, Liadova A, McCormack N, Ivory R, McKie VA, Ormerod A, McCleary BV (2017) Novel substrates for the automated and manual assay of endo-1,4- $\beta$-xylanase. Carbobydr. Res. 445: 14-22. https://doi.org/10.1016/j.carres.2017.02.009

Miller GL (1959) Use of dinitrosalicylic acid reagent for determination of reducing sugar. Anal. Chem. 31: 426-428. https://doi. org/10.1021/ac60147a030
Mizerska-Dudka M, Jaszek M, Blachowicz A, Rejczak TP, Matuszewska A, Osinska-Jaroszuk M, Stefaniuk D, Janusz G, Sulej J, Kandefer-Szerszen M (2015) Fungus Cerrena unicolor as an effective source of new antiviral, immunomodulatory, and anticancer compounds. Int. J. Biol. Macromol. 79: 459-468. https://doi.org/10.1016/j.ijbiomac.2015.05.015

Muheim A, Waldner R, Sanglard D, Reiser J, Schoemaker HE, Leisola MSA (1991) Purification and properties of an aryl-alcohol dehydrogenase from the white-rot fungus Phanerochaete chrysosporium. Eur. J. Biochem. 195: 369-375. https://doi.org/10.1111/j.1432-1033.1991. tb15715.x

Naganagouda K, Salimath PV, Mulimani VH (2009) Purification and characterization of endo-beta-1,4 mannanase from Aspergillus niger gr for application in food processing industry. J. Microbiol. Biotechnol. 19: 1184-1190. PMID: 19884778

Osorio-Concepcion M, Cristobal-Mondragon GR, Gutierrez-Medina B, Casas-Flores S (2017) Histone deacetylase HDA-2 regulates Trichoderma atroviride growth, conidiation, blue light perception, and oxidative stress responses. Appl. Environ. Microbiol. 83. https://doi. org/10.1128/AEM.02922-16

Pawlik A, Mazur A, Wielbo J, Koper P, Żebracki K, Kubik-Komar A, Janusz G (2019a) RNA sequencing reveals differential gene expression of Cerrena unicolor in response to variable lighting conditions. Int. J. Mol. Sci. 20: 290. https://doi.org/10.3390/ijms20020290

Pawlik A, Ruminowicz-Stefaniuk M, Frac M, Mazur A, Wielbo J, Janusz G (2019b) The wood decay fungus Cerrena unicolor adjusts its metabolism to grow on various types of wood and light conditions. PLOS ONE. 14: e0211744. https://doi.org/10.1371/journal. pone.0211744

Pérez J, Muñoz-Dorado J, de la Rubia T, Martínez J (2002) Biodegradation and biological treatments of cellulose, hemicellulose and lignin: an overview. Int. Microbiol. 5: 53-63. https://doi.org/10.1007/ s10123-002-0062-3

Proietto M, Bianchi MM, Ballario P, Brenna A (2015) Epigenetic and posttranslational modifications in light signal transduction and the circadian clock in Neurospora crassa. Int. J. Mol. Sci. 16: 15347-15383. https://doi.org/10.3390/ijms160715347

Roody WC (2003) Mushrooms of West Virginia and the Central Appalachians. University Press of Kentucky

Sánchez C (2009) Lignocellulosic residues: biodegradation and bioconversion by fungi. Biotechnol. Adv. 27: 185-194. https://doi. org/10.1016/j.biotechadv.2008.11.001

Schmoll M (2018a) Regulation of plant cell wall degradation by light in Trichoderma. Fungal Biol. Biotechnol. 5: 10. https://doi.org/10.1186/ s40694-018-0052-7

Schmoll M (2018b) Light, stress, sex and carbon - the photoreceptor ENVOY as a central checkpoint in the physiology of Trichoderma reesei. Fungal Biol. 122: 479-486. https://doi.org/10.1016/j.funbio.2017.10.007

Sulej J, Janusz G, Osińska-Jaroszuk M, Rachubik P, Mazur A, Komaniecka I, Choma A, Rogalski J (2015) Characterization of cellobiose dehydrogenase from a biotechnologically important Cerrena unicolor strain. Appl. Biochem. Biotechnol. 176: 1638-1658. https://doi. org/10.1007/s12010-015-1667-2

Tisch D, Schmoll M (2010) Light regulation of metabolic pathways in fungi. Appl. Microbiol. Biotechnol. 85: 1259-1277. https://doi. org/10.1007/s00253-009-2320-1

Wang Z, Wang JR, Li N, Li JG, Trail F, Dunlap JC, Townsend JP (2018) Light sensing by opsins and fungal ecology: NOP-1 modulates entry into sexual reproduction in response to environmental cues. Mol Ecol. 27: 216-232. https://doi.org/10.1111/mec.14425

Wariishi H, Valli K, Gold MH (1992) Manganese(II) oxidation by manganese peroxidase from the basidiomycete Phanerochaete chrysosporium. Kinetic mechanism and role of chelators. J. Biol. Chem. 267: $23688-23695$

Yoshida Y, Maeda T, Lee B, Hasunuma K (2008) Conidiation rhythm and light entrainment in superoxide dismutase mutant in Neurospora crassa. Mol. Genet. Genomics. 279: 193-202. https://doi.org/10.1007/ s00438-007-0308-Z

Yoshida Y, Iigusa H, Wang NY, Hasunuma K (2011) Cross-talk between the cellular redox state and the circadian system in Neurospora. PLOS One 6. https://doi.org/10.1371/journal.pone.0028227

Yu Z, Fischer R (2019) Light sensing and responses in fungi. Nat. Rev. Microbiol. 17: 25-36. https://doi.org/10.1038/s41579-018-0109-x 